\title{
SOCIAL RESPONSIBILITY AND INTERNATIONAL LAW: REFLECTIONS ABOUT LABOUR ISSUES
}

\author{
Corinne Gendron
}

ESKA | « Revue de l’organisation responsable »

2013/2 Vol. 8 | pages 49 à 62

ISSN 1951-0187

ISBN 9782747224369

Article disponible en ligne à l'adresse :

https://www.cairn.inforevue-de-l-organisation-responsable-2013-2-page-49.htm

Distribution électronique Cairn.info pour ESKA.

(C) ESKA. Tous droits réservés pour tous pays.

La reproduction ou représentation de cet article, notamment par photocopie, n'est autorisée que dans les limites des conditions générales d'utilisation du site ou, le cas échéant, des conditions générales de la licence souscrite par votre établissement. Toute autre reproduction ou représentation, en tout ou partie, sous quelque forme et de quelque manière que ce soit, est interdite sauf accord préalable et écrit de l'éditeur, en dehors des cas prévus par la législation en vigueur en France. Il est précisé que son stockage dans une base de données est également interdit. 


\title{
SOCIAL RESPONSIBILITY AND INTERNATIONAL LAW: REFLECTIONS ABOUT LABOUR ISSUES
}

\section{Corinne GENDRON}

gendron.corinne@uqam.ca

\begin{abstract}
While many analysts greet the success of corporate social responsibility around the world, others are concerned that it might be a substitute for binding regulations, which are then prevented from emerging.

According to such critical perspective, globalization and neo-liberalism are part of the same movement in which the normative power of states is being transferred to private actors, with the twofold consequence of consecrating the principle of self-regulation while elevating companies to the status of real legislators. This critical perspective interprets social responsibility initiatives and mechanisms as a movement to privatize law, inherent in the neo-liberal ideology that drives the globalization movement.

While seductive, this perspective is the antithesis of what is argued here, that is, that the social responsibility movement reflects a transformation of juridicization which is beyond its control and which is part of a broader democratic evolution, itself the result of both social dynamics and globalization.

This article explores the forms taken by social responsibility in the field of labour in order to bring out the limitations of the critical perspective and reflect on the relationships between law and democracy in our economic and globalized societies. Building on ISO 26000 adoption process, it shows that social responsibility initiatives do not abolish existing legislation and are not adopted "in place of" binding instruments. On the contrary, by juxtaposing themselves with international laws, those initiatives or mechanisms participate in their effectiveness.
\end{abstract}

Keywords: Social responsibility, ISO 26000, Globalisation, Self-regulation, International law, Labor law, Privatisation of law.

\section{RÉSUMÉ}

Tandis que plusieurs analystes saluent le succès de la responsabilité sociale à travers le monde,

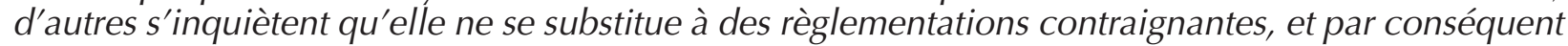
en freine l'adoption.

Selon cette perspective critique, la mondialisation et le néolibéralisme s'inscrivent dans un même mouvement à travers lequel le pouvoir normatif des États a été transféré à des acteurs privés, avec pour double conséquence d'instituer les entreprises en véritables législateurs et de consacrer le principe d'autorégulation. Cette perspective critique interprète les initiatives et les mécanismes de responsabilité sociale comme un mouvement de privatisation du droit, inhérent à l'idéologie néolibérale qui sous-tend la mondialisation.

Bien que séduisante, cette perspective est à l'opposé de la thèse présentée ici, selon laquelle le mouvement de la responsabilité sociale traduit une transformation de la juridicité qui le dépasse, en s'inscrivant plus largement dans une évolution de la démocratie qui résulte à la fois de la dynamique sociale et de la mondialisation. 
Cet article analyse les formes que prend la responsabilité sociale dans le domaine du travail afin de mettre en lumière les limites des analyses critiques et de montrer les relations entre droit et démocratie dans nos sociétés économiques mondialisées. En prenant appui sur l'expérience d'ISO 26000, il montre que les initiatives de responsabilité sociale n'abolissent ni ne remplacent la règlementation contraignante. En se juxtaposant au droit international, elles contribuent plutôt à son effectivité.

Mots-clés : Responsabilité sociale, ISO 26000, Mondialisation, Autorégulation, Droit international, normes du travail, Privatisation du droit.

I $\mathrm{n}$ recent years, corporate social responsibility (CSR) has dominated the discourses of all social actors and been embodied in a vast number of mechanisms ${ }^{1}$. While many analysts greet this success as heralding a new era of "re-responsibilization" among economic actors (Webb, 2013), others are concerned about this trend towards viewing social responsibility as a substitute for binding regulations, which are then prevented from emerging.

Thus, a stream of literature which is critical of CSR sees the latter as an integral part of a neo-liberal strategy of deregulation, which replaces traditional norms with voluntary initiatives that are not only ineffective but have also been developed unilaterally by private actors. The worldwide diffusion of the neoliberal order means along with a privatization which, beyond the tools of production, affects the norms which control them. International institutions are increasingly marginalized in the building process of the normative order, with multinational corporations taking the leadership. Private actors are becoming producers of norms of lex mercatoria but also of international economic agreements in the conclusion of which they participate just like states. Globalization has contributed to displace the production of norms from public authorities toward private actors (Chassagnard-Pinet and Delalieux, 2013, p. 4).

According to this analysis, globalization and neoliberalism are part of the same movement in which the normative power of states is being transferred to private actors, with the twofold consequence of consecrating the principle of self-regulation while elevating corporations to the status of legislators. Social responsibility initiatives therefore entail "broadening the areas of power held by transnational corporations" (Soussi, 2013) while the latter become the legal entrepreneurs of a privatized normative system: "Companies may be considered 'legal entrepreneurs,' in the same way as Howard Becker speaks of 'moral entrepreneurs" (Daugareilh, 2007, p. 45).

This critical perspective interprets social responsibility initiatives and mechanisms as a movement to privatize law, inherent in the neo-liberal ideology that drives the globalization process. Armed with this diagnosis, it condemns corporate control over prerogatives that are normally devolved to states, emphasizing the need for states to come back to social regulation. From this perspective, social responsibility not only appears to offer self-regulation as a poor substitute for traditional regulation, but also appears to be a real threat to democracy given that norms of coexistence are prescribed by private actors. Driven by its own interests in a market space that is devoid of benevolence, how can a company legitimately assume this role of social regulation?

This perspective, while seductive, is the antithesis of what I want to argue here, that is, that the social responsibility movement reflects a transformation of juridicization and that it is part of a broader democratic evolution, itself the result of both social dynamics and globalization. Although it is undeniably imbued with the interests of dominant actors through the interplay of power relations that drives all societies, the social responsibility movement nevertheless cannot be interpreted strictly as a neo-

1. I would like to thank my translators as well as the reviewers who generously shared valuable comments on my original manuscript, which a preliminary french version has been published under the title «Les initiatives et les dispositifs de responsabilité sociale menacent-ils le droit international : réflexions à partir d'ISO 26000 en matière de droit du travail " in Brunelle D. Travail et commerce. Clauses sociales, responsabilité sociale et accords transnationaux d'entreprises, Montréal, Éditions IEIM, 223 p., pp. 55-92. 
liberal strategy that has been intentionally devised by these actors. Rather, it reflects a new dynamic which seeks to meet the challenges involved in social regulation at the global level and also results from the transformation of the relationship between civil societies and the state at the national level. I am not suggesting that this development is necessarily beneficial or leads to undeniable democratic progress, but I propose that it brings about innovations that need to be understood before being condemned as private neoliberal strategies. It is therefore important to grasp both the limitations and potentials of this emerging regulatory order rather than becoming alarmed about the order that is disappearing or deploring an ideal order that will never happen.

In my view, the criticism that social responsibility represents a privatization of law is based on a series of misunderstandings regarding its definition, but also regarding the nature and effectiveness mechanisms of law. The first misunderstanding relates to the fact that only a tiny fragment of social responsibility phenomenon is considered by its critics, whereby it is reduced to the definition given by specific social actors. But as illustrated by the ISO 26000 guidelines on social responsibility adopted in late 2010 , social responsibility is broad and has many forms and dimensions. It cannot be summed up simply as "voluntary initiatives that exceed legal obligations." The second misunderstanding results from a restrictive understanding of law and its effectiveness mechanisms which, in particular, considers social responsibility as a substitute for, rather than an addition to traditional legal norms. Yet, in practice, social responsibility draws from existing legislation (Lachèze, 2008), and the normative activity of private actors very often corresponds to an appropriation of public norms (Daugareilh, 2013), thus participating to its effectiveness. Lastly, the critical perspective unfortunately equates national legal orders with international legal order by setting the national state system up as an ideal referent for international governance. However, developing global law on an international scale involves a completely different logic from that which is observed within states since, at the global level, the authority is shared by a vast number of actors with divergent interests (DelmasMarty, 2007). This means that global goals such as those relating to climate change depend on multinational participation wherein each state modulates its commitment based on its own economic interests, traditional alliances, and industry structure (Audet, 2013). The international space, which was not involved in the contingencies leading to the building of nation states, organizes the issues based on changing geopolitical equilibriums. Thus, postulating the establishment of a central authority in this space whereby the interests of actors would be institutionalized amounts to denying the specificity of this space and ignoring its real dynamics.

This article explores the forms taken by social responsibility in the field of labour at the international level in order to bring out the limitations of the critical perspective and reflect on the relationships between law and democracy in our economic and globalized societies. I analyse how ISO 26000 formalises labor issues as a result of multi stakeholder participation in the writing process of the guidelines. I then propose to see the deliberative mechanisms associated with social responsibility as a regulatory innovation required by the globalization context rather than as a substitute for stringent regulation. But before laying the foundations for this analysis, a clarification of what I mean by "social responsibility" is in order.

\section{SOCIAL RESPONSIBILITY AND ISO 26000}

The expression "social responsibility" is complicated since it refers simultaneously to what is deemed to be the objective responsibility of a company, the initiatives and mechanisms said to meet this responsibility, and at times even the idea that a company can be a moral subject. However, the meaning that is most often given to it is drawn from the managerial perspective of social responsibility which postulates a possible self-regulation of economic actors. This managerial perspective, which emerged in the United States at the beginning of the century, has advocated, in turn, exemplary behaviour on the part of corporate leaders, dialogue with stakeholders, and the integration of social and environmental dimensions into corporate performance without waiting for corporations to be forced to do so by law. Hence, the definition which is most widely adopted and has even been institutionalized in some legal texts refers to social responsibility understood as "a voluntary measure that exceeds legal obligations and a dialogue with the stakeholders." ${ }^{2}$

This definition certainly refers to a practical reality; however, it is misleading to reduce social responsibility to that practical reality. As shown by Durkheim, researchers must be wary of pre-notions and strive to deconstruct objects as they present

2. See, in particular, the former definition of the European Commission: "A concept whereby companies integrate social and environmental concerns in their business operations and in their interaction with their stakeholders on a voluntary basis." European Commission. 2001. Green Paper "Promoting a European Framework for Corporate Social Responsibility," COM(2001) 366, July 2001. 
themselves in order to grasp the underlying reality. When conducting any analysis, Touraine (2003) more specifically suggests distinguishing the action from the explanation of it given by the actors involved. Therefore, researchers who are interested in social responsibility must first focus on identifying the phenomenon outside the definitions proposed by the actors, while integrating these different definitions into their analysis. Defining social responsibility as "voluntary initiatives that exceed legal obligations" thus derives from a double error that involves reducing the phenomenon to the definition given by some actors and overlooking the diversity of viewpoints in the analysis.

Although most discourses are coloured by the idea that social responsibility is voluntarily assumed by economic actors who thus claim to self-regulate, a contrary viewpoint nevertheless exists according to which social responsibility can only result from a binding framework, as illustrated by the comments made in 1999 by Duff Conacher, head of Democracy Watch:

Large Canadian corporations and transnational corporations are especially influential. Because of the sheer size of these corporations, the decisions of the relatively few people who control them exert great influence on the decision-making of local, provincial and national governments, and can have great impact on the communities in which these corporations are located. For these reasons, there is a need for a social responsibility framework for large corporations and TNCs especially, a framework that enables individual citizens and communities to hold corporations accountable to community interests. ${ }^{3}$

The comparison of these two perspectives shows that, beyond the solutions for regulating corporations put forward by social actors, social responsibility brings a questioning of the contribution made by corporations to the progress and well-being of societies, and of the delimitation of their perimeter of action. It thus raises fundamental questions regarding the autonomy of economic actors in relation to politics - an autonomy recast by the context of globalization.

However, social responsibility is embodied not only in these myriad discourses but also in the multiple mechanisms that fuel the confusion over its true nature: voluntary or mandatory, unilateral or multipartite, social or legal, private or public, and so on. When scholars move beyond the discourse of actors in order to grasp the phenomenon in its tangible manifestations, they are initially struck by the multiplicity and diversity of mechanisms associated with or claiming to represent social responsibility. They are then surprised to discover, for example, that these mechanisms are rooted in the traditional legal system. This is obvious in the reports on sustainable development or social responsibility, which overwhelmingly refer to the various laws and regulations when promoting responsible corporate behaviour (Caron and Gendron, 2012). In fact, social responsibility is rooted in law because, even without being explicitly acknowledged, it is precisely the laws which define the rights and duties making up this responsibility. Moreover, a new generation of laws refer explicitly to social responsibility by relying on its new mechanisms (Desbarats, 2013), while the judiciary, for its part, sets social responsibility up as a norm of behaviour. In the famous BCE ruling, the Court states, for example, that:

In each case, the question is whether, in all the circumstances, the directors acted in the best interests of the corporation, having regard to all relevant considerations, including, but not confined to, the need to treat affected stakeholders in a fair manner, commensurate with the corporation's duties as a responsible corporate citizen. ${ }^{4}$ Thus, far from being unrelated to law or going against it, social responsibility directly draws from it in multiple ways (Lachèze, 2008).

An analysis also reveals that, far from pertaining to private actors only, social responsibility initiatives are often promoted by NGOs and even by governments. For example, the NGO Yamana, which is active in the textile sector, was subsidized upon its creation by the Ministère français des Affaires Étrangères (MAE, French Ministry of Foreign affairs), while the Ethical Trading Initiative, for its part, received considerable support from the British Government (ChassagnardPinet and Delalieux, 2013, p. 9). In fact, as demonstrated by Vallée and al., even initiatives that are presented as unilateral pertain to a pluralistic dynamic: "the codes of conduct of multinational corporations cannot be considered as resulting solely from self-regulatory practices, but are the outcome of multiple interactions between state and non-state legal orders" (2001, p. 6; trans.). ${ }^{5}$ In fact, to obtain the effect sought for in terms of image, relations with protesters or risk reduction, even a so-called "unilateral" initiative must necessarily be developed in accordance with institutionalized norms and in close collaboration with the main corporate interlocutors. Outside this dialogue with the institutional framework and the social actors, a social responsibility

\footnotetext{
3. Conacher, D. 1999. Cited in Canadian Democracy and Corporate Accountability Commission. Canadian Democracy and Corporate Accountability. An Overview of Issues. 2001.

4. BCE Inc. v. 1976 Debentureholders, 2008 SCC 69, [2008] 3 S.C.R. 560 at para. 82 [BCE].

5. Furthermore, voluntary initiatives are often deployed in anticipation of legislation: Silverstein D. 1987. "Managing Corporate Social Responsibility in a Changing Legal Environment," American Business Law Journal, Vol. 25, 1987, pp. 523-566.
} 
initiative remains ineffective with regard to the benefits that the company itself hopes to reap from it. The forestry sector helps to illustrate this dynamic. In addition to the FSC Certification from the Forest Stewardship Council initiated by social and environmental NGOs in partnership with corporations and forest owners, several industrial (SFI) and governmental certifications were developed and ultimately brought together under the Programme for the Endorsement of Forest Certification (PEFC). These "industrial" certifications, i.e. close to industry interests, were denounced as certificates of convenience and are still rejected by the main environmental NGOs which support FSC Certification. Given that the SFI certification and the PEFC are worthless to these NGOs, they have almost no impact on the reputational risk of corporations since they cannot protect them against the environmentalists negative campaigns. Aware of these limitations, managers often consider obtaining industrial certifications, which are less demanding, as a first step, with the aim of obtaining FSC Certification in the medium term in order to gain the support of protesters (Lafrance, 2006; Maurais, 2006).

In fact, the main social responsibility mechanisms are multipartite, which does not mean that corporations have no influence over them, but that those mechanisms cannot be reduced to unilateral corporate initiatives. Mechanisms such as the Global Reporting Initiative (GRI), Forest Stewardship Council (FSC) or, more recently, ISO 26000 are particularly important because many actors in dialogue have worked out compromises regarding what is expected from corporations. Moreover, while not prejudging their effectiveness, it would be mistaken to suggest that, within these mechanisms, only corporations prescribe norms.

The process of developing ISO 26000 - the Social Responsibility Standard - aptly illustrates this issue. Since the International Standardization Organization realized that it needed to get away from its usual process of drafting a standard in order to earn legitimacy in the field of social responsibility, it established a particularly innovative system of international social dialogue. The Technical Group usually responsible for drafting the standard made room for six categories of actors called on to give their opinion and agree on a definition of corporate social responsibility: consumers, workers, NGOs, governments, industry and "other actors" (consultants, universities, etc. under the SSRO acronym for Service Support Research and Others). As reported by Ornella Cilona, member of the Italian General Confederation of Labour (CGIL) and
President of the Technical Committee on Social Responsibility of Organizations in the Italian Standards Body (UNI): "Seven plenary meetings of the Group were held between 2005 and 2010 at which discussions on procedures occasionally became heated" (Cilona, 2013, p. 29)

At the end of five years of negotiations, the participants agreed on an exhaustive text which contains abundant references to international conventions in defining the responsibilities of organizations, while at the same time being the outcome of a dialogue between actors from more than 90 countries: "The Working Group agreed on the crucial principle that every part of ISO 26000 should be written by consensus - i.e., without sustained opposition - of all six categories of stakeholder" (Cilona, 2013, p. 29). Although this SR Standard is undoubtedly imperfect (Daugareilh, 2011), it can not be reduced to the voice of industry alone, even though the latter was, together with the governments, the most active participant in its development (Hahn and Weidtmann, 2012; Pena, 2011).

\section{ISO 26000 AND LABOUR AS A COLLECTIVE ISSUE}

Beyond the controversies that it continues to arouse, the ISO 26000 Standard clarifies the issues involved in social responsibility, proposes a terminology for it and explains the formal or informal standards with which corporations must comply. It structures the obligations of organizations around six core subjects: human rights, labour practices, the environment, fair operating practices, consumer issues and, lastly, community involvement and development. Far from adhering to the managerial perspective of CSR mentioned above, ISO 26000 views social responsibility as an exercise of compliance with legal and social norms as well as the product of a dialogue between the firm and its stakeholders. It thus advocates a managerial style that is open to stakeholders, whose concerns the corporations must take into account and with whom they must engage in dialogue. Moreover, voluntary initiatives are only valid insofar as they are developed within the framework of this dialogue, which can be prone to conflict (sub-clause 7.8).

Many observers assume that the process followed in developing ISO 26000 will foster broad support for this standard, in particular, given its exhaustive text which contains more than one hundred pages and, with the exception of taxation, covers a wide range of social issues. The SR Standard could thus play an

6. About the ISO 26000 writing process, see Hahn and Weidtmann (2012). 


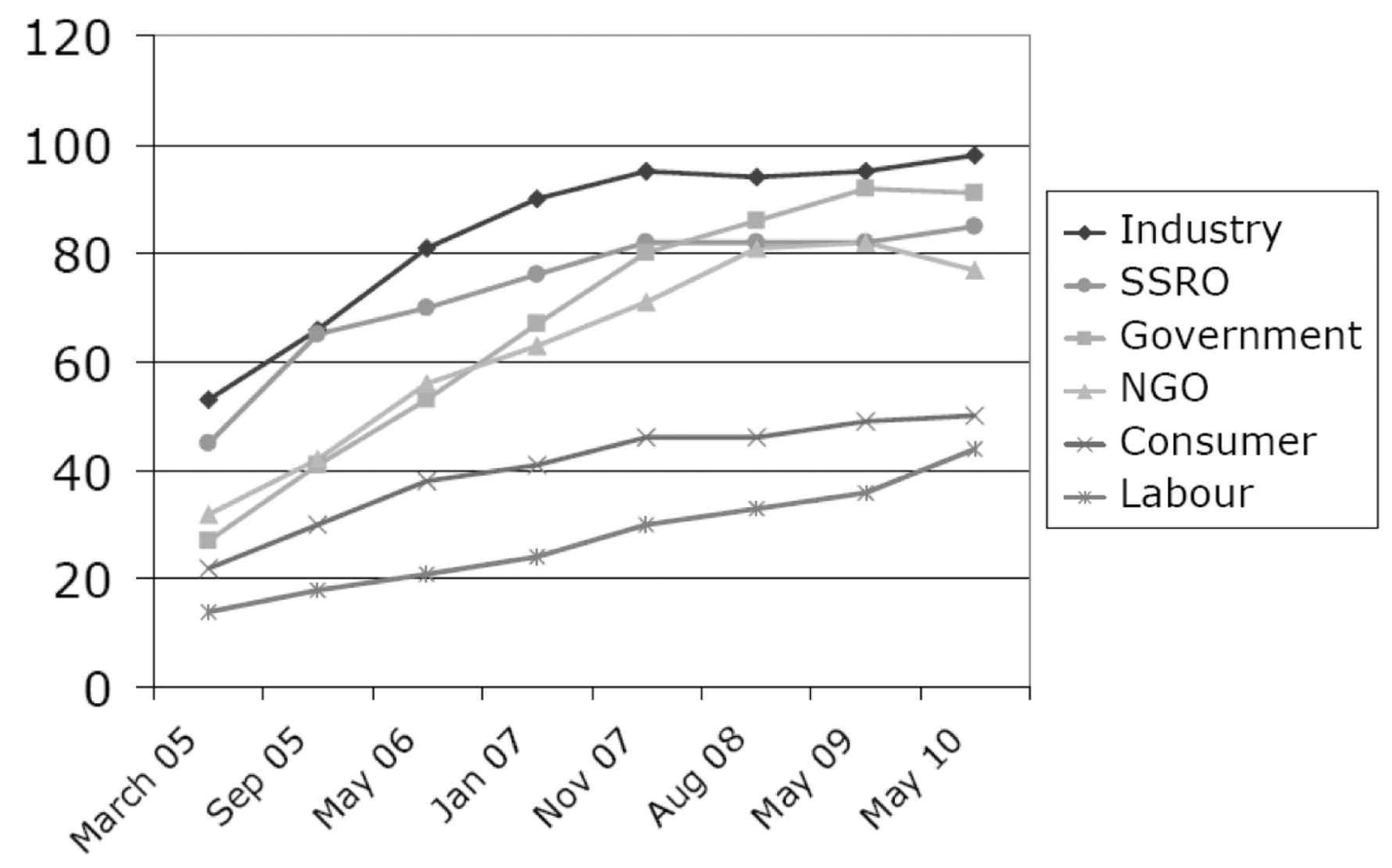

Table 1: Relative participation of categories of stakeholder in the process of developing ISO 26000, from March 2005 to May 2010.

Source: Report of Secretariat of Working Group on Social Responsibility (WGSR), 17 May 2010.

important role in the field of social responsibility, especially since it stems from the ISO, an organization that is close to industry: "It will certainly be an additional norm but one that is singularly appealing to trade and business, and even to consumers since it comes from the ISO" (Daugareilh, 2011, p. 160; trans.). Thus, it merits analysis, especially by those who are interested in how labour issues are structured in the field of social responsibility.

As mentioned above, not all social actors participated with the same intensity in developing ISO 26000 (Pena, 2011). The trade unions were the least involved, which raised fears that labour issues might be treated deficiently or inadequately, especially in their collective dimension. As stated by the Italian trade unionist Ornella Cilona:

Trade unions were the least well-represented stakeholders in the ISO Social Responsibility Working Group for two reasons. First, shortage of funding prevented many trade unionists from attending the eight plenary meetings: the ISO could only fund attendance for a few from emerging economies. Second, many national standards bodies did not ask the unions to serve on the Mirror Committees (national equivalents) that were to track preparation of the standard. Even so, trade unions did manage to get a comprehensive distillation of responsible labour practices consistent with ILO international labour standards written into ISO 26000 (Cilona, 2013, p. 29).

It should be mentioned that union organizations were initially opposed to this process, fearing that, if the ISO dealt with themes pertaining to ILO jurisdiction, these themes would be removed from the tripartite dynamic. As reported by Michel Capron and Thierry Dedieu, who participated in the process:

When the negotiations started, the ICFTU (International Confederation of Free Trade Unions which, in 2006, merged with the World Confederation of Labour to form the International Trade Union Confederation) called for the boycott of the ISO and only decided to participate when the ISO's relationship with the International Labour Organization was clarified. [...] The unions (...) warned the ILO to be wary since, for international trade unionism, what mattered was that the ISO would not challenge what had been developed under a United Nations tripartite system (Auberger, 2010, p. 5; trans.).

Moreover, the national union organizations were still quite unfamiliar with and most often suspicious of a so-called "social responsibility" process. As Capron and Dedieu explained: "The call for participation [from the ICFTU] did not immediately and clearly reach the affiliated organizations, which caused some problems. In general, union commitment was unclear since CSR and sustainable development were still fledgling issues for union organizations, in particular 
among corporate teams" (Auberger, 2010, p. 5; trans.).

Nevertheless, the union participants, strengthened by the formal agreement concluded between the ILO and the ISO, ${ }^{7}$ but also familiar with international negotiation processes, managed to effectively defend their position, such that: "the coordination of trade unionists throughout the world by the ICFTU, and later by the ITUC, resulted in quite a strong voicing [of workers' interests]. [...] In the end, the Guidance on SR refers to the ILO conventions and the ILO played a significant role [in developing the standard]" (ibid.; trans.).

Having thus been developed with the ILO's support, the content of ISO 26000 in the field of labour law was readily approved by the trade unions; this has directly contributed to its legitimacy in the field and may facilitate its diffusion within corporations since, in contrast with other standards, the SR Standard can be relayed in the organization by both management and the unions. As stated by Sharon Burrow, General Secretary of the International Trade Union Confederation, upon the adoption of ISO 26000 in fall 2010:

We support the emphasis given to authoritative international instruments in this text [ISO 26000] as well as the recognition that it is not for individual organisations to unilaterally define the interests of society. Only the ILO has the mandate to set international standards that impact upon the world of work. Furthermore, support for ISO 26000 does not mean that we would support further ISO standards relative to workers and their workplaces. Private standards must not become a substitute for public policy established through democratic and representative political processes. (ITUC, 2010).

The success of union participation in the process of drafting ISO 26000 is reflected in the importance attached to the question of labour in this standard. In addition to the focus on Labour Practices $(6.4)^{8}$ as a key labour issue, the relative frequency of the terms "work" and "worker/s" used in the text shows that labour is indeed a priority issue. " A more detailed analysis shows how the SR Standard conceive the labour question, in particular with regard to the collective nature of issues affecting workers. Based on the ILO Declaration of Philadelphia, the text points out that labour is not a commodity and consequently: "this means that workers should not be treated as a factor of production and subjected to the same market forces that apply to commodities" (6.4.2.1). Labour and its remuneration are presented as essential contributions of organizations to society, ${ }^{10}$ although, in order to deal with the issues raised by globalization, the SR Standard liberates the employment relationship from formal frameworks so that subcontracting can be integrated into it.

The text emphasizes the need for labour law, stating that "the fact that the power of the contracting parties is not equal and that employees therefore require additional protection [...] forms the basis for labour law" (6.4.3.1). At the same time, it recognizes that collective mechanisms are an integral part of labour practices. ${ }^{11}$ These collective mechanisms figure prominently in the section on the Fundamental Principles and Rights at Work (6.3.20) which were adopted directly from the ILO, ${ }^{12}$ and led to a series of "related actions and expectations":

\footnotetext{
7. Ruwet explains that "the signing of a MoU between the ILO and the ISO greatly affected how the content of the SR Standard was developed by conferring an a priori legitimacy and status of authority on the International Labour Organization. This status was manifested mainly through its presence in all strategic groups, as well as a quasi right of veto over the decisions made. The ILO was thus put in a position of superiority in relation to the contributions and criticisms made by other participants in the process, more particularly with regard to matters related to its conventions. This position was generally recognized and considered as legitimate by a majority of participants in the ISO 26000 development process" (Ruwet, 2012; trans.). The formal agreement concluded between the ISO and the ILO specifically reiterates ILO authority over labour matters. See: Memorandum of Understanding between the International Labour Organization and the International Organization for Standardization in the Field of Social Responsibility: http://inni.pacinst.org/inni/corporatesocialresponsibility/MoU\%20ILO\%20\&\%20ISO.pdf

8. The section on Labour Practices (6.4) addresses employment and employment relationships (6.4.3), conditions of work and social protection (6.4.4), social dialogue (6.4.5), health and safety at work (6.4.6) and human development (and training in the workplace) (6.4.7). ISO 26000 makes abundant reference to ILO conventions, to which, moreover, it devotes a box (Box 8, p. 41).

9. The term "work" is used 312 times and the term "employment" 12 times, compared to 110 instances for the expression "human rights" and 30 instances for the term "environment." "Workers" are cited 100 times, in addition to 43 references to "employees," 21 references to "employers" and 6 references to "trade unions." In comparison, the SR Standard cites "consumers" 151 times and the more general category of "stakeholders" 268 times. Lastly, the International Labour Organization is mentioned 72 times, whereas the WTO is cited twice, the OECD 8 times and the United Nations 88 times. It is interesting to note that in the introductory section relating to the definitions, the SR Standard distinguishes the term "employee" from the term "worker," explaining that the first term is more restrictive than the second (2.5). The term "employee" refers to an "individual in a relationship recognized as an "employment relationship" in national law or practice whereas the term "worker" refers to "anyone who performs work, as an employee or someone who is self-employed" (2.27).

10. "The creation of jobs, as well as wages and other compensation paid for work performed are among an organization's most important economic and social contributions. Meaningful and productive work is an essential element in human development, standards of living are improved through full and secure employment. Its absence is a primary cause of social problems. Labour practices have a major impact on respect for the rule of law and on the sense of fairness present in society: socially responsible labour practices are essential to social justice, stability and peace" (6.4.1.2).

11. "Labour practices also include the recognition of worker organizations and representation and participation of both worker and employer organizations in collective bargaining, social dialogue and tripartite consultation (see Box 8) to address social issues related to employment." (6.4.1.1). 12. The SR Standard specifies that the Fundamental Principles and Rights at Work are centred on work-related areas for action. They were adopted by the international community as fundamental human rights and, as such, are addressed in the section relating to Human Right. The SR Standard refers to each of these rights in specific sub-clauses: freedom of association and effective recognition of the right to collective bargaining, the elimination of all forms of forced or compulsory labour, the effective abolition of child labour and the elimination of discrimination in respect of employment and occupation.
} 
6.3.10.2 Related actions and expectations [relating to the Fundamental Principles and Rights at Work]

Although these rights are legislated for in many jurisdictions, an organization should independently ensure that it addresses the following matters:

- freedom of association and collective bargaining [29][68] The right for workers and employers to establish and join organizations of their own choosing without previous authorization, subject to respect for the rule of law. Representative organizations formed or joined by workers should be recognized for purposes of collective bargaining. Terms and conditions of employment may be fixed by voluntary collective negotiation where workers so choose. Workers' representatives should be given appropriate facilities that will enable them to do their work effectively and allow them to perform their role without interference. Collective agreements should include provisions for the settlement of disputes. Workers' representatives should be provided with information required for meaningful negotiations. (See 6.4 for further information on freedom of association and the relationship that exists between freedom of association and collective bargaining, on the one hand, and social dialogue on the other hand.)

Another section of the SR Standard is devoted to social dialogue which "is based on the recognition that employers and workers have both competing and mutual interests" (6.4.5.1). Defined as "negotiation, consultation or simple exchange of information between or among representatives of governments, employers and workers, on matters of common interest relating to economic and social concerns," social dialogue is understood within the meaning given to it by the ILO. Thus, although it constitutes a form of dialogue with the stakeholders, it is distinguished from the latter by its regulated dimension. ${ }^{13}$

This dialogue, whose conflictual ${ }^{14}$ nature is not ignored by the SR Standard, helps to avoid costly social confrontations and ensure smooth functioning within the organization, and can also be a vector of innovations. It is within this spirit that the SR Standard specifies that wages and working conditions result from collective bargaining processes between the employer and the workers. ${ }^{15}$ Moreover, social dialogue is conditional on the parties being independent: "Worker representatives should be freely elected, in accordance with national laws, regulations or collective agreements, by either the members of their trade union or by the workers concerned. They should not be designated by the government or the employer" (6.4.5.1). Social dialogue can also involve the working conditions of sub-contractors. The SR Standard also emphasizes the development of international social dialogue, which is "a growing trend, and includes regional and global dialogue and agreements between organizations operating internationally and international trade union organizations." It formulates the related actions and expectations in the area of social dialogue as follows:

6.4.5.2 Related actions and expectations

An organization should [20][26][78]:

- recognize the importance for organizations of social dialogue institutions and applicable collective bargaining structures, including at the international level;

- respect at all times the right of workers to form or join their own organizations to advance their interests or to bargain collectively;

- not obstruct workers who seek to form or join their own organizations and to bargain collectively, for instance by dismissing or discriminating against them, through reprisals or by making any direct or indirect threat so as to create an atmosphere of intimidation or fear;

- where changes in operations would have major employment impacts, provide reasonable notice to the appropriate government authorities and representatives of the workers, so that the implications may be examined jointly to mitigate any adverse impact to the greatest possible extent; - as far as possible, and to an extent that is reasonable and non-disruptive, provide duly designated work representatives with access to authorized decision makers, to workplaces, to the workers they represent, to facilities necessary to perform their role and to information that will allow them to have a true and fair picture of the organization's finances and activities; and

- refrain from encouraging governments to restrict the exercise of the internationally recognized rights of freedom of association and collective bargaining. For example, organizations should avoid establishing a subsidiary or sourcing from

13. The SR Standard specifically identifies collective bargaining processes among the forms of dialogue that an organization can engage in with its stakeholders (5.3.3), and recognizes the existence of legal obligations relating to dialogue with regard to employees (5.3.3, p. 18).

14. See 5.2.1 and 5.3.2: "Some stakeholders are an integral part of an organization. These could include the members or employees of the organization, as well as the shareholders or other owners of the organization. It should be recognized that these stakeholders share a common interest in the purpose of the organization and in its success. This does not mean, however, that all their interests with respect to the organization will be the same."

15. "In determining wages and working conditions that reflect these considerations, the organization should bargain collectively with the workers or their representatives, in particular the unions, where they so wish, in accordance with national systems for collective bargaining [60][61]" (6.4.4.2). 
companies established in specialized industrial zones where freedom of association is restricted, or even non-existent, even if this right is recognized by national regulation; organizations should refrain from participating in incentive schemes based on such restrictions.

As can be seen, the SR Standard requires that organizations recognize the institutions that are pertinent to social dialogue and provide them with the means to carry out their activities (facilities, information...). They must respect the right to organize and bargain collectively and avoid schemes aimed at preventing unionization, both in their organization and at government level. Lastly, organizations must inform the governments and workers' representatives, in a timely manner, of any changes in their operations likely to have an impact on employment, so as to allow the latter to come up with measures to mitigate the impact. ${ }^{16}$

However, the SR Standard remains impervious to joint management. ${ }^{17}$ The section on governance gives little attention to employees and does not mention trade unions or workers, while the chapter on the integration of social responsibility throughout an organization refers more generally to stakeholders (69) times) and only a few times to employees (4 instances). The SR Standard merely aims to "encourage effective participation of all levels of employees in the organization's decision making on issues of social responsibility" in the "decision-making processes and structures" (6.2.3.2). The section on health and safety at work, on the other hand, provides for a role for workers and their organizations by advocating the creation of joint labour-management health and safety committees ${ }^{18}$ and refers to workers' organizations in the related actions and expectations: "An organization should [...] base its health, safety and environment systems on the participation of the workers concerned [...] and recognize and respect the rights of workers [...] to seek outside advice from workers' organizations, employers and others who have expertise" (6.4.6.2).

Lastly, the Annex relating to tools for social responsibility lists several initiatives put forward by the trade unions and NGOs involved in labour law and human rights issues such as the Clean Clothes Campaign (CCC), ${ }^{19}$ Ethical Trading Initiative (ETI), ${ }^{20}$ Fair Labour Association (FLA), ${ }^{21}$ Fair Wear Foundation (FWF), ${ }^{22}$ Social Accountability International (SAI), ${ }^{23}$ and Business Social Compliance Initiative (BSCI). ${ }^{24}$ It also refers to international framework agreements (IFAs) defined as "Agreements negotiated between transnational enterprises (TNEs) and Global Union Federations (GUFs) designed to provide a means of addressing problems mainly related the labour practices in the operations of a specific multinational company at the international level." 25

This analysis shows that ISO 26000 incorporates various viewpoints, in particular that of trade unions. Therefore, it cannot be interpreted as a standard stemming mainly from corporations. ${ }^{26}$ Moreover, the idea that it is an exclusively private standard should be questioned given the participation of the ILO and various states in its development. Furthermore, as pointed out by Daugareilh, ISO 26000 does not

16. In this respect, see also sub-clause 6.4.3.2 which specifies that an organization should: "provide reasonable notice, timely information and, jointly with worker representatives where they exist, consider how to mitigate adverse impacts to the greatest possible extent when considering changes in its operations, such as closures that affect employment [72][73]."

17. This could be explained as a union strategy to limit their involvement to issues pertaining to fundamental rights, as suggested by the comments reported by Ruwet: "We are careful not to participate too much. (...) I try to minimize ILO participation to only what is really relevant to protect the labour standard to make it clear that it isn't an ILO standard, it's an ISO standard. We want to help the ISO to get (...)” (Interview conducted in Lisbon in May 2006 with the ILO representative) (Ruwet, 2012).

18. "Worker representatives on these committees should not be appointed by management but elected by the workers themselves. Membership in these committees should be equally divided among management and worker representatives and should include both men and women whenever possible. The committees should be of sufficient size for all shifts, sections and locations of the organization to be represented. They should not be considered a substitute for trade unions or works councils" (Box 9, p. 48).

19. Clean Clothes Campaign: International association of national organizations in 12 European countries dedicated to improving working conditions in the garment industry and to defending workers in the industry seeking change. CCC campaigns on specific cases and engages with companies and authorities to resolve them. The CCC also provides information about the working conditions and labour practices in the industry and has a benchmark code. www.cleanclothes.org

20. Membership organization open to companies, NGOs and specific trade union organizations. The purpose is for sourcing companies to work with NGOs and trade unions to learn about the best ways to implement supply chain codes of labour practice. Companies pay membership fees, agree to apply code of labour practices to their suppliers, report on activities and observe other requirements. www.ethicaltrade.org/

21. Multi-stakeholder initiative established to address supply chain labour practices. Participants include sourcing companies, colleges and universities and NGOs. Participating companies must support the monitoring and verification of working conditions of their suppliers. The FLA issues public reports. www.fairlabor.org/

22. A multi-stakeholder organization established to address supply chain labour practices in the clothing and footwear sector. Sourcing companies become members of FWF by making an annual contribution, adopting a Code of labour Practices and observing other requirements. Companies are evaluated annually for compliance with this code. www.fairwear.nl (in Dutch).

23. Multi-stakeholder organization addressing supply chain labour practices. Sets auditable SA 8000 standard for workplaces. An independent organization, "Social Accountability Accreditation Services (SAIS), accredits providers of certification to SAI 8000. SAI produces the Handbook for Implementing a Socially Responsible Supply Chain Management System and other tools. Organizes conferences and training on supply chain labour issues. www.sa-intl.org

24. Industry initiative that focuses on labour practices in the supply chains of mainly large retail companies. Most members are retailers and marketing companies who pay membership fees and agree to audit suppliers against a code of conduct. The initiative certifies the auditors. www.bsci-eu.org 25. See: http://www.global-unions.org/spip.php?heading70

26. Which does not mean that corporations do not produce standards, on the contrary. However, in contrast to what is suggested in some studies, corporate standards cannot be equated with social responsibility standards and vice versa. 
innovate in the field of labour law but merely reproduces former commitments and refers to the best practices associated with them: "[ISO 26000] is not more or less than a reformulation in its own language, obscure at times, of notions, concepts and principles of law. (...) It is a standard that was developed to respond to society's demand for the regulation of corporate activities, but it adds nothing new in terms of substance and form to alreadyexisting international instruments. Its distinctive feature resides in the procedure used in its development, its value added in its scope of application and its power given the authority of the organization from which it stems" (2011, p. 160; trans.). Thus, ISO 26000 corresponds less to a production of norms than to an appropriation of existing law by new instruments participating to its effectiveness. Moreover, although the SR Standard is presented as a voluntary tool, it could very well become a mandatory tool under legislative and case law developments, since it is established as a contractual requirement in commercial relations or as a condition for dialogue with social movements. Thus, it would be misleading to equate it with a unilateral self-regulatory initiative.

\section{THE CSR MOVEMENT AS A REGULATORY INNOVATION}

Because the participatory mechanisms for public policy development, which emerged in the late 1980s, were deployed during a wave of deregulation, there was a tendency to criticize them as part of this wave. But one should not forget the fierce controversy aroused by previous mechanisms. In a report of the Law Reform Commission of Canada, Schrecker (1984) stated that:

At both provincial and federal levels, regulatory policy with respect to environmental hazards is normally made on the basis of negotiations between the agency concerned and the firms or industries whose actions are the target of the proposed policy initiative. These negotiations are usually conducted in secret. Those individuals or groups not party to the negotiations are seldom entitled to information about their substance, or even of their existence.

Thus, according to Schrecker, the Parliamentary hearings on the Environmental Contaminants Act (1975) were undertaken only after consultations with the chemical industry, which resulted in two preliminary drafts of the legislation. Consequently, the chemical industry welcomed the Act "while environmental organizations like the Canadian Environmental Law Association contended that the legislation contained numerous shortcomings" (1984, p. 7). The process of developing regulations was also consistent with this logic:
Regulations for specific industries are normally developed on the basis of the conclusions of informal task forces or steering committees composed of representatives of industry and of the federal and provincial governments. Others do not participate. The task forces have generally taken "a best practicable technology" approach in determining desired control levels. This system essentially precludes any technology-forcing role for regulation, since industry's arguments about the economic feasibility of emissions reductions are not subject to scrutiny and challenges by third parties (1984, p. 8). Thompson concluded that, with regard to environmental issues, "... bargaining is the essence of the environmental regulatory process as it is practised in Canada (...) The norms of conduct are the subject of negotiation and renegotiation between the regulator and the regulated right down to the moment of compliance or non-compliance... Only if there is an ultimate disagreement is the enforcement procedure utilized, and even then its role may be but another step in a drawn out negotiation process" (1981, p. 33, cited by Schrecker, 1984, pp. 8-9).

However, in 1987 a report of the National Task Force on Environment and Economy recognized that the complexity and proliferation of social, economic and environmental problems had given rise to questions and increasing demands for participation from various population groups, forcing corporations and governments to review their decision making processes (1987, p. 10):

The desire for participation extends beyond specific projects. It includes an interest in the planning and policy making that affect the country's environmental and economic future. Many sectors of Canadian society, embodying different interests, want a meaningful role in these fundamental processes. These groups include environmental organizations, labour, small business, academics and aboriginal peoples among others. There are many points of view and many interests in economic and environmental issues. Each of these is important. No single point of view, in isolation, can adequately reflect the complexity of the interests involved (1987, p. 10). Although this report made no reference to the deliberations of the Law Reform Commission of Canada, it nevertheless suggested a direct alternative to the procedure that had been criticized by it. This alternative involved opening up negotiations to the broader civil society as part of a transparent process of dialogue. It was in this spirit that it recommended that national round tables on the environment and the economy be created to provide a forum to actors who, until then, had been excluded from public policy development processes:

We [The Task Force] recommend a new process of consultation which will involve senior decision makers from these diverse groups. (...) These 
Round Tables are intended to be forums in which senior decision makers can meet to candidly discuss environment-economy issues and make recommendations directly to the First Ministers of their respective jurisdictions. Round Tables should also report their conclusions directly to the public (1987, p. 10).

These mechanisms were at times seen as an attempt by the state to abandon its regulatory responsibility, but one can also recognize in those mechanisms an attempt to formalise an Habermasian dialogue, while noting its limitations. According to Turcotte who followed several of these processes, in many cases, the social actors could not agree on the key elements in a given regulation project, while the government was reluctant to play its role as arbiter (Turcotte, 1997; Turcotte \& Ali, 2002). These mechanisms nevertheless represented a real innovation in terms of public policy development, and it is therefore simplistic to equate them with a neo-liberal strategy to privatize law. The mechanisms for dialogue implemented in the 1990s were meant to begin a regulatory process, and did not claim to replace it as can be seen in the wording of the recommendation made by the Task Force on Environment and Economy. It was the simultaneous context of deregulation which very often delayed the expected legislative sanction inherent in the process.

According to several observers, these consultation and public debate procedures, which became generalized in the late 1980s, were closely related to the contemporary forms of collective action (Bouchard \& Hamel, 1996). In fact, a direct relationship can be seen with the new social movements which, in contrast with the labour movement, characteristically deployed their action outside traditional institutional mechanisms (Touraine, 1973; Offe, 1985). This had the effect of transforming the public space which has since been marked by a "new logic of institutional action which fosters forms of self-organization beyond the state and which thus contributes to a rearrangement of institutions that have served so far as the carriers of modern rationality" (Eder, 1993, p. 14). This new logic is certainly linked with the way the social counter-powers of protestors are structured around executive power (Rosanvallon, 2006). As shown by the Report of the National Task Force on Environment and Economy, civil society initiatives are thus indissociable from the new consultation procedures established by the state. These participatory procedures have reshaped the modes of public intervention and reformulated the democratic dynamic, such that:
(...) the practices associated with deregulation cannot be reduced to the autonomization of market forces. They are also (and perhaps this is where their scope is most significant) the illustration of a new type of behavioural regulation through state action, pertaining to a "new architecture of social complexity" ${ }^{27}$ (Issalys, 1999, p. 83 ; trans.).

However, although the new social movements have participated in these new mechanisms, their action has extended beyond them. As carriers of projects and contesting ideologies, they developed new social norms and, since the 1990s, have proposed another way of formalizing them in order to compensate for the inadequacies of traditional regulation exacerbated by an essentially economic structuration of the global space. The forestry certification initiative, for example, was supposed to be a response to the inability of international institutions and states to protect forests. Fair trade, for its part, advocated correcting an international economic regulation that was perceived to be unfair. All these initiatives are less a manifestation of the "privatization of law" than a proliferation of regulatory spaces on the margin of the state. This relates to a more complex and more fundamental transformation inherent in evolving social dynamics and the challenges that globalization poses for a social regulation having democratic pretentions.

In this respect, as explained by Delmas-Marty, while we cannot "transpose the model of the national government to a supranational, regional or global authority," neither can we "confine ourselves to a purely international organization of the world" (2007; trans.). The coordination needed at this level is all the more complex since global issues and universal principles must be rooted in national sovereignties, while being sustained by non-state actors. This is precisely why globalization has led to a "surprising diversification" of regulation techniques (Moreau, 2004). To sum up, while the concepts of internormativity and hybridity are increasingly relevant in terms of understanding the legal dynamics on the national scene, they are also essential for understanding the international legal order (DelmasMarty, 2007). They refer to the plurality of normative spaces, the multiplicity of legal instruments and the ordering of pluralism, an issue that henceforth comes up on both national and international scenes.

In this perspective, it can be suggested that, in some way, ISO 26000 organizes the many obligations formalized by numerous instruments at the global level ${ }^{28}$. However, this does not solve the question of its status. Is it a legal norm? In what way does it pertain

27. Thuot J.-F. 1998. La fin de la représentativité et les formes contemporaines de la démocratie, Québec, Nota Bene, p. 182.

28. Pena (2011) also explains that: "The framework (of ISO 26000) not only moved away from previous ISO functioning, but also differed from other governance schemes such as tripartism, multilateralism, multistakeholder standardisation and self-regulation, all of them institutional developments intended to augment, in diverse contexts, the legitimacy and efficacy of increasing complex norm-setting processes ». (p. 10). 
to the legal order and what effect does it have? Can it be considered as a legitimate norm?

ISO 26000 has been repeatedly criticized on account of its non-binding nature and because of the danger that this soft law might replace traditional regulations (hard law). ${ }^{29}$ However, this criticism ignores the complexity of law and its effectiveness mechanisms. On the one hand, effectiveness is not the prerogative of hard law, as explained by Duplessis regarding international labour law: "Some soft norms are effective even though they do not result from any of the procedures covered by the theory of sources of international law, regarded by lawyers as the only ones which generate binding legal obligations" (Duplessis, 2008, p. 16). Indeed, this effectiveness is based on the participation of actors in the development of norms, which legitimizes the participatory processes explained above. As stated by Javillier:

Along the demanding and uncertain path towards making law effective, appropriation is undoubtedly a key stage. In a rule of law (...), such a stage seems to go without saying or even be superfluous. A legal rule should be enough on its own: the constraint to apply it is evident and produces the expected effects in almost all circumstances. However, experience shows that legal rules, and the principles on which they are based, are constantly under review: to give them full practical scope, preparatory work, education, acculturation and lastly appropriation are crucial. A legal rule should never just constrain; it also has to convince as it must in a democratic order (2008, pp 52-53).

On the other hand, soft law completes rather than replaces hard law:

The function of soft law is to ensure the completeness of the legal system by incorporating the practices of the actors involved. It weaves a normative fabric that plugs the gaps in hard law, occupies the areas abandoned by the official legal channels and builds bridges between the different forms of international law-making generated by having a number of different international actors. (...). The subject-matter dealt with in a soft instrument becomes subject to the expectations of members of the international community in more or less the same way as with hard norms, and regardless of whether there are sanctions involved. While soft law may lack binding force as defined in legal theory, this does not mean that it does not have legal effects which are themselves the sign and product of ongoing cooperation and competition between the actors of an international community which now lacks comparability. (Duplessis, 2008, p. 27).

Thus, ISO 26000 does not abolish existing legislation and has not been adopted "in place of" binding instruments. On the contrary, by juxtaposing itself with international laws, which it makes easier to appropriate by corporate actors, it participates in their effectiveness, which could then be strengthened by other mechanisms, such as integration into national laws and case laws, contractual conditionality, commercial certification, basis for dialogue with social actors, or simply as a management referential. Moreover, it involved previously excluded sociopolitical actors in a deliberative structure which allowed to reach consensual understanding and concepts beyond traditional opposition between given social actors (Pena, 2011).

\section{CONCLUSION}

In view of its tangible manifestations, corporate social responsibility supersedes the definitions and motivations advanced by social actors. Nor is it an unequivocal expression of a dominant power. Rather, its primary mechanisms are a new way of defining norms which represents a kind of crossover between the judicial and the social and which seeks to use market dynamics as a tool for law effectiveness. ${ }^{30}$ However, while we must dismiss the notion of social responsibility as a dangerous privatization of law in favour of corporate self-regulation, this does not mean that social responsibility is a regulatory panacea in the global era. Indeed, the dangers are located elsewhere.

As pointed out by several analysts, recognizing the spaces of non-state regulation raises the difficult issue of the legitimacy of the norms stemming from them. Even if a subsequent institutionalization might respond, at least partially, to this issue, such an institutionalization will also have its limitations. As explained by Audet (2013a, p. 216) regarding organic certification, integrating a mechanism into the traditional legal system certainly changes the initial normative project conceived by its initiators, such that there now exists, for example, a type of organic industrial farming that is officially recognized by the state, but is far removed from the founding ideals of the organic movement (Baqué, 2012).

However, in my view, the greatest danger lies in the fact that by equating CSR with a particular social actor, these new regulatory spaces consecrate

29. On the subject of soft law, see Georges Abi-Saab, "Éloge du 'droit assourdi.' Quelques réflexions sur le rôle de la soft law en droit international contemporain," in Nouveaux itinéraires en droit. Hommage à François Rigaux, Bruxelles, Bruylant, 1993, pp. 59-68.

30. As explained by the concepts of the new social economic movement (Gendron, 2001), non-state market-driven regulatory instruments (Cashore, 2002) or political consumerism (Micheletti, 2003). Economic pressures are, moreover, one of the main levers of international trade law, and can be put to use in the social or environmental sphere (Banks, 2012). 
corporations as a legitimate participant in the democratic debate. I do not argue, as suggested by some scholars, that social responsibility extends the zone of influence of corporations; indeed, this extension precedes it. Rather, I am concerned about the fact that the discourse surrounding it puts forward a legitimizing motivation for it. As pointed out above, based on the analyses of Schrecker (1984), it is true that corporations already participated in the development of norms, but it was in a concealed way. The social responsibility discourse tends, on the contrary, to institute corporations as a legitimate actor in civil regulation spaces, within the formal mechanisms of participatory democracy and on an international scale. Yet, the corporation is not a social actor, but rather an institution that organizes interests and classifies individuals in a hierarchical way. Giving it a formal voice within the democratic debate implies consecrating this order, and thus denying the formal equality between citizens postulated by democracy while locking the societal project in an expression that is primarily, if not exclusively, commercial and economic. The corporation embodies a certain view of coexistence and consecrates an ordering of interests whose presuppositions correspond to political choices that should be open to debate. By giving a voice to the company as it is constituted, we allow it to defend its constitutive principles in all arenas open to it and even help to make them evolve in favour of its dominant actors.

In this context, it is important to consider the status of the participants in a democratic debate whose procedures have been profoundly shaken. Questions are already being asked regarding the legitimacy of NGOs and their representativeness (Delmas-Marty, 2007). In my view, the participation of corporations gives rise to even more complex issues. It is certainly necessary to question their status as a legitimate actor in the political arena. ${ }^{31}$ However, since they are no longer merely economic operators but orient our societies, they should be also questioned, and even rethought as institutions that are integrated into a democratic order. The concept of corporate citizenship so favoured in much of the discourse on social responsibility tends to take the legal architecture of the company out of the discussion. In fact, this social institution needs to be reconstructed so that it can effectively respond to the environmental and social challenges of our time in a democratic way.

\section{BIBLIOGRAPHY}

Abi-Saab, G. 1993. "Éloge du 'droit assourdi'. Quelques réflexions sur le rôle de la soft law en droit international contemporain," in Nouveaux itinéraires en droit. Hommage à François Rigaux, Bruxelles, Bruylant.

Auberger M.-N. 2010. "Une rencontre avec Michel Capron et Thierry Dedieu." La Missive de Gestion Attentive - No. 43 November 2010 - page 5/10.

Audet R. 2013. "Climate justice and bargaining coalitions: a discourse analysis," International Environmental Agreements Politics, Law and Economics.

Audet R. 2013a. "Certifications: la construction d'un cadre régulatoire hybride" in C. Gendron and B. Girard, Repenser la responsabilité sociale de l'entreprise - L'Ecole de Montréal -, éd. Armand Colin, coll. Recherches, 2013, pp. 215-230.

Banks K. 2012. "Trade, Labour and International Governance" Paper presented at the workshop Travail et commerce : clauses sociales, accords cadres internationaux et responsabilité sociale des entreprises. Les Ateliers de l'IEIM. Montréal, 17-18 October, 2012.

Baqué P. (ed.). 2012. La bio entre business et projet de société, Contre-feux, Agone, 2012, 428 p.

Bouchard, A. and P. Hamel. 1996. "Consultation publique et action collective: une évaluation sociopolitique à partir du cas de Montréal." In Action collective et décentralisation, edited by Côté et al., pp. 141-155. Rimouski (Qué.): GRIDEQ-GRIR.

Caron M.-A. et Gendron C. 2012. «Faire entrer la responsabilité sociale de l'entreprise en démocratie ", ROR, Vol. 7, No 1, 2012, p. 5-17.

Cashore, B. 2002. "Legitimacy and the Privatization of Environmental Governance: How Non-State Market-Driven (RMNÉ) Governance Systems Gain Rule-Making Authority." Governance: An International Journal of Policy, Administration, and Institutions. Vol. 15, No. 4, pp. 503 - 529.

Chassagnard-Pinet S. and G. Delalieux. 2010, "Contractualization of the social and environmental norms," Legal Research Network, Groningen, the Netherlands, October 21-22, 2010

Chassagnard-Pinet S. and G. Delalieux. 2013. "La privatisation des normes sociales et environnementales : codes de conduite, chartes privées, mécanismes privés de certification : Congrès RIODD-ESEE, Lille, June 2013.

Cilona O. 2013. Trade union involvement in non-technical standardization, spring-summer 2013/HesaMag\#07, Special report 19/25.

Confédération Syndicale Internationale. 2010. La CSI soutient la nouvelle norme internationale sur la responsabilité sociale. 21 septembre 2010. http://www.ituc-csi.org/la-csi-soutient-lanouvelle-norme?lang=fr consulted on August 10, 2013/ International Trade Union Confederation. 2010. ITUC Supports New International Standard on Social Responsibility. 20 September 2010.

Daugareilh, I. 2008. "Corporate norms on CSR and International norms," in J.-C. Javillier, Governance, International Law \& Corporate Social Responsibility, Research Series 116, ISBN 978-92-9014-860-9, ILO International Institute for Labour Studies (IILS), Geneva, 2008, pp. 63-78.

Daugareilh, I. 2011. "La norme ISO 26000 sur la responsabilité sociétale des organisations : observations sur une expérience d'inter-normativité," in M. Capron, F. Quairel-Lanoizelée, 
M.F.Turcotte, ISO 26000 : une Norme 'hors norme?, Economica ed., Paris, 2010, pp. 147-163.

Daugareilh, I. 2013. "Le droit à l'épreuve de la RSE," in C. Gendron and B. Girard, Repenser la responsabilité sociale de l'entreprise - L'École de Montréal -, éd. Armand Colin, coll. Recherches, 2013, pp. 199-214.

Delmas-Marty M. 2007. Les forces imaginantes du droit III : La refondation des pouvoirs, Éditions du Seuil, Paris, 2007, 299 p.

Desbarats I. 2013. "La RSE à la française, entre incitations et contraintes," in C. Gendron and B. Girard, Repenser la responsabilité sociale de l'entreprise - L'École de Montréal -, éd. Armand Colin, coll. Recherches, 2013, pp. 183-197.

Duplessis I. 2008. "Soft international labour law: The preferred method of regulation in a decentralized society," in J.-C. Javillier, Governance, International Law \& Corporate Social Responsibility, Research Series 116 DP/182/2007, ISBN 978-92-9014-860-9, ILO International Institute for Labour Studies (IILS), Geneva, 2008, pp. 7-36.

Eder, K. 1993. "Social Movements and Democratic Order ", in Citizenship, Markets, and the State, edited by Colin Crouch, Klau Eder, Damian Tambini, Oxford University Press, 2000.

Gendron C., 2001. "Émergence de nouveaux mouvements sociaux économiques," Paris : Revue Pour, No. 172, December 2001, pp. 175-181.

Groupe de travail national sur l'environnement et l'économie. 1987. Rapport du Groupe de travail national sur l'environnement et l'économie. Table ronde nationale sur l'environnement et l'économie, 36 pages.

Groupe de travail sur ISO 26000, ISO/TMB/WG SR, 8th meeting Copenhagen, Denmark, 17 - 21 May 2010. http://isotc.iso.org/livelink/livelink/fetch/-\%208929321/ 8929339/8929348/3935837/8742970/9225278/6\%2CReport ofthesecretariat $\% 2$ CCopenhagen. $\% 20$ pdf?nodeid $=9224951 \& \mathrm{v}$ ernum $=-2$

Hahn, R. \& Weidtmann, C. 2012, "Transnational Governance, Deliberative Democracy, adn the Legitimacy of ISO 26000: Analyzing the Case of a Global Multistakeholder Process", Business and Society, XX(X) 1-40.

Issaly, P. 1999. "Figures et avenir de la déréglementation," Éthique publique, Vol. 1, No. 2, pp. 83-91.

Javillier J.-C. 2008. "Corporate Social Responsibility and law: Synergies are needed for sustainable development," in J.-C. Javillier, Governance, International Law \& Corporate Social Responsibility, Research Series 116 DP/182/2007, ISBN 978-929014-860-9, ILO International Institute for Labour Studies (IILS), Geneva, 2008, pp. 37-62.

Lachèze A. 2008. "Le droit comme source et ressource pour l'action en matière de RSE," III Séminaire de recherche Responsabilité sociale de l'entreprise et marchés, CERTOP and LIRHE, Toulouse, November 20-21, 27 p.

Lafrance M.-A., 2006, Le potentiel de la certification à favoriser la mise en auvre d'une foresterie durable, Master's dissertation, UQAM, p.

Maurais J. 2006, Transformations régulatrices induites par l'arrivée de la certification forestière au Québec, Master's dissertation, UQAM, p.

Micheletti M. 2003. Political Virtue and Shopping: individuals, shopping and collective action. New York: Palgrave Macmillan.
Moreau, M-A. 2005. "La recherche de nouvelles méthodes de régulation sociale : quelles fonctions, quelle complémentarité." EUi Working Paper Law, No. 08.

Offe C. 1985. "New Social Movements: Challenging the Boundaries of Institutional Politics," Social Research, 52, pp. 817868.

Pavageau P. 2012. "RSE : Gagner un capital de sympathie pour gagner la sympathie du capital. Un risque de fragilisation du droit du travail, le point de vue de FO (Force ouvrière)" Revue internationale de l'économie. 03/05/2012, online: http://recma. org/node/1908 consulted on August 11, 2013.

Peña, A. M. 2011. ISO and Social Standardisation: Uncomfortable compromises in Global Policy-Making (Report No. CUTP/009A). London, $24 \mathrm{p}$.

Rosanvallon P. 2006. La contre-démocratie. La politique à l'âge de la défiance, Seuil, Points-Essais, No. 598, 2008.

Ruwet C. 2012. "La RSE négociée : règles du jeu et contenus. Le cas d'ISO 26000," Négociations 2/2012 (No. 18), pp. 93-108.

Schrecker, T.F. 1984. Lélaboration des politiques en matière d'environnement, Commission de réforme du droit du Canada, Série protection de la vie, 124 p. /Political Economy of Environmental Hazards, Law Reform Commission of Canada, Protection of Life Series.

Sobzak A. 2004. "La responsabilité sociale de l'entreprise : menace ou opportunité pour le droit du travail," Relations industrielles/Industrial Relations, 2004, p. 26.

Thuot, J.-F. 1998. La fin de la représentativité et les formes contemporaines de la démocratie, Québec, Nota Bene.

Touraine A. 1973. Production de la société. Paris : Éditions du Seuil.

Touraine, A., "Les méthodes de la sociologie" in Serge Moscovici and Fabrice Buschini (ed.), Les méthodes des sciences humaines, Paris, Presses Universitaires de France, 2003.

Turcotte, M.-F. 1997. La prise de décision par consensus : leçons d'un cas en environnement, Paris : L'Harmattan, collection Logiques sociales, 172 pages.

Turcotte, M.-F. and Ali, B. 2002. "Lessons from a Broken Partnership: the Case of ARET," in Bruijn, Theo J.N.M. and Arnold Tukker (eds), Partnership and Leadership -Building Alliances for a Sustainable Future, Kluwer Academic Publishers, Dordrecht, 2002.

Vallée, G. 2003. "Les codes de conduite des entreprises multinationales et l'action syndicale internationale : réflexions sur la contribution du droit étatique," (2003) 58: 3 Relations industrielles 363-394.

Vallée, G. 2005. "Responsabilité sociale de l'entreprise et droit du travail," in A. Salmon and M.-F. Turcotte (ed.), La responsabilité sociale et environnementale des entreprises, SainteFoy, Presses de l'Université du Québec, 2005, pp. 171-200.

Ward, H. (2012) ISO 26000 and global governance for sustainable development. International Institute for Environment and Development. London.

Webb, K. 2013 "Entreprises, de la déresponsabilisation à la reresponsabilisation," in C. Gendron and B. Girard (eds), Repenser la responsabilité sociale de l'entreprise. L'École de Montréal, Paris : Armand Colin. 429 p., pp. 63-76. 